\title{
Primary School Teachers Perceptions Towards Preschool Education
}

\author{
$1^{\text {st }} \mathrm{D}$ Hendriawan \\ Childhood Education Study Program \\ Universitas Pendidikan Indonesia \\ Indonesia \\ derihendriawan@gmail.com \\ $4^{\text {th }}$ I R Ridwan \\ Childhood Education Study Program \\ Universitas Pendidikan Indonesia \\ Indonesia
}

\author{
$2^{\text {nd }}$ Susilawati \\ Childhood Education Study Program \\ Universitas Pendidikan Indonesia \\ Indonesia
}

$5^{\text {th }}$ Tiurlina

Childhood Education Study Program

Universitas Pendidikan Indonesia

Indonesia

\author{
$3^{\text {rd }} \mathrm{N}$ Sundari \\ Childhood Education Study Program \\ Universitas Pendidikan Indonesia \\ Indonesia
}

\author{
$6^{\text {th }}$ Fatihaturosyidah \\ Childhood Education Study Program \\ Universitas Pendidikan Indonesia \\ Indonesia
}

\begin{abstract}
This study discusses the perceptions and opinions of the primary school teachers about whether or not for primary students go to the kindergarten first. Respondents of this study are the primary school teacher who have immeasurable teaching experience. The data were collected by interviewing $\mathbf{4 0}$ primary school teachers who are selected randomly. The teachers especially have had been teaching for about 11 to 18 yearsteaching experience. Based on the data collection and results of the study, it can be concluded that $85 \%$ of the teachers admitted that they did not encounter any obstacles in teaching students who are not go to kindergarten before they go to the primary school. In other words, kindergarten education did not give any significance to the primary school teacher in their teaching process to the students.
\end{abstract}

Keywords-Primary School, Teahers, Preschool, education

\section{INTRODUCTION}

Education is carried out the interests of children in the future as the nation's successors. This is in accordance with the United Nations Convention on the Rights of the Child which states that "the purpose of education is to prepare children to be a responsible individual to live their life society in freedom, in the spirit of understanding, peace, tolerance, gender equality, and friendship among all people, ethnic, national and religious groups and people of indigenous origin [1]. Education is a wise effort to realize the sustainable development of a nation. Education plays an important role in creating the wise and qualified human resources who are responsible to carry out sustainable development [2]. The concept of education for sustainable development is a separate concept because it is an important matter. Education for sustainable development must takea part in all levels of education, start from early childhood education to tertiary education [3]. It is undeniable that the condition of early childhood education which is the first and main education is still facing obstacles. Based on the analysis of the situation there are several things that cause obstacles in early childhood education, including the first aspect in terms of quality, where the understanding of the community about early childhood education is still at low level. Secondly, regulations and governance regulations are inadequate and lack of access. Third, community and parents' involvement in the services is not at the optimum level. Thus, the problem in this research is related to the early childhood education and primary school education as a continuous level. The results of this study emerged a response to the need of early childhood education for basic education significance based on the elementary school teachers' perceptions. This case also related to how the role of early childhood education for basic education should be. Whether or not the child's ability to read, write and count become a must before entering elementary school. Such of this question were then answered by the respondents, the elementary school teachers, as users of early childhood education graduated children. After completing education, students must be equipped with competencies that can be used to anticipate various challenges and opportunities [4]. This research seeks to build harmony in the transition between early childhood education and primary school which felt not to be optimum. In further research, it can be done to strengthening the supporting curriculum to optimize the learning experience of the transition to elementary school level. Learning experiences acquired by children can improve their higher-order thinking skills, which are the skills is needed for members of the community [3]. This research emphasizes the need to prepare early childhood learning experiences before entering the level of basic education through the possibility of curriculum reform both in early childhood education or in primary school. Curriculum reform can be carried out to deal with 21st century globalization in terms of cultural diversity, ethnic diversity, and global society through 
developing critical thinking capacity [3]. Research findings indicate that there are the needs to be good communication and synergy between early childhood education teachers and elementary school teachers, both institutionally and professionally. The implication of the next research is to suggest the development of transition competencies that are understood by early childhood education teachers and elementary school teachers, especially for the teachers who is teaching at low level class grade [5].

\section{METHODOLOGY}

This research uses survey methods to collect data quantitatively and interview methods to collect data qualitatively [6]. The interview is aimed to describe primary school teachers' perceptions about preschool education. The sample in this study are teachers in primary school which are grouped using cluster sampling techniques based on their background education, their class grade teaching at and their teaching experience length which are 1-10 years and 10-20 years.

The research also applied a structured interview for instrument that had been developed in three steps, review various articles in journals and manuals in the field of primary school education, identify the competencies of preschool graduates and test the validity and reliability of questions through expert judgment. Data collection procedures used structured interviews in the form of analytical descriptive with discriminatory power of each item. Interviews were conducted directly to the respondents.

\section{RESULTS}

This study aims to identify primary school teacher perceptions toward preschool education. This perception was identified based on their respond to the questions of the interview. The results of the interview can be seen in table 1 below.

TABLE I. RESPONDENT DATA, CLASSIFICATION, AND PERCENTAGE OF ANSWERS

\begin{tabular}{|l|l|c|}
\hline \multicolumn{1}{|c|}{ Respondent Data } & \multicolumn{1}{|c|}{ Classification } & $\begin{array}{c}\text { Percentage } \\
\text { of Answers }\end{array}$ \\
\hline \multirow{2}{*}{ Teaching Experience } & $1-10$ Year & 50 \\
\cline { 2 - 3 } Grade Class & $11-20$ Year & 50 \\
\hline \multirow{5}{*}{ Education Background } & Lower Class & 43 \\
\cline { 2 - 3 } & High Class & 57 \\
\hline \multirow{2}{*}{ Gender } & $\begin{array}{l}\text { Teacher Primary } \\
\text { Education }\end{array}$ & 77 \\
\cline { 2 - 3 } & $\begin{array}{l}\text { Non Teacher Primary } \\
\text { Education }\end{array}$ & 23 \\
\hline & Woman & 82 \\
\cline { 2 - 3 } & Man & 18 \\
\hline
\end{tabular}

Table 1 shows details of respondent data, classification, and percentage of answers. The results of the interview are then analyzed, through analysis of the description of the data presented in the form of quantitative data [21]. Respondent data consists of teaching experience, grade class to teach, educational background and gender. The first data respondents in the form of teaching experience are classified into two types namely they who have been teaching for about 1 to 10 years exerience and they who have been teaching for about 10 to 20 years. The result shows that the percentage of both has the same percentage, that is $50 \%$. The second data respondent is the class grade where they are teaching at when this interview done. This data is also classified into two groups namely respondents who is teaching the lower class (grades 1-3) and responedent who is teaching the upper class (grades 4-6). Respondent data shows that teachers who is teaching in lower class are $43 \%$ and teachers who is teaching in upper class are $57 \%$. The third respondent data is related to educational background. In this case, the educational background of teachers is divided into two types, namely teacherswho has primary school education background and teachers who has other education background or nonprimary school education background. From the results of the classification, there is $77 \%$ of teachers with primary school teacher education backgrounds and $23 \%$ of teachers who is not from primary school teacher education backgrounds. The fourth respondent data is related to gender where there are asignificant number between female respondents and male respondents which are $82 \%$ for female respondents and $18 \%$ for male respondents. The classification of thisinterview results is classified into seven categories. The classification of respondents' interview results regarding their perceptions of early childhood education and their percentage can be seen in table II.

TABLE II. ANSWER CLASSIFICATION AND PERCENTAGE OF ANSWERS

\begin{tabular}{|l|c|}
\hline \multicolumn{1}{|c|}{ Answer Classification } & $\begin{array}{c}\text { Percentage } \\
\text { of Answers }\end{array}$ \\
\hline Pre-school is not important & 5 \\
\hline Not a Regulation / Not Mandatory & 8 \\
\hline School Location & 10 \\
\hline Child's Family Economic Conditions & 10 \\
\hline Not Differentiating Children's Ability & 12 \\
\hline Age of the child & 40 \\
\hline Required to Pre-School & 15 \\
\hline
\end{tabular}

Table 2 shows the classification of interview results into seven categories. The first classification with a percentage of $15 \%$ means that entering pre-school education is a must. The second classification with a percentage of $40 \%$ means that to enter primary school, the most important thing is the age of the child must fit intoits minimum qualification, that is 6 or 7 years old. The third classification with a percentage of $12 \%$ means that that there are some differencies ability between children who graduated from pre-school education and theywho are not. The fourth classification with a percentage of $10 \%$ means that the economic condition of the family does not support children to attend preschool education. The fifth classification with a percentage of $10 \%$ means that the location of the primary school is in the remote village or the absence of pre-school education in their neighborhood of the children. The sixth classification with a percentage of $8 \%$ means that there are no regulations to push the children to go to any pre-school education first before they go to primary school. The seventh classification with a percentage of $5 \%$ means that the respondents thought that 
preschool education is not important. They knowledged that learning activity in pre-school is only playing.

\section{DISCUSION}

The identification of elementary school teachers' perceptions is influenced by various aspects. This following is the results of the interview which is classified into seven answers. The first answer with a percentage of $5 \%$ of answers is based on two respondents' answers, who state that "there is no need to enter kindergarten, because in kindergarten, students only do play so even though they do not go to kindergarten before, they still can be accepted in elementary schools". While another respondent stated "children do not have to go to kindergarten first. Essentially, elementary school is the first level of education for children. There is no correlation between kindergarten and elementary school. Because kindergartens are informal schools. So, even students did not go to kindergarten, they will still be accepted in elementary schools. " Both respondents' answers can be interpreted that kindergarten education is not so important because the teaching material in kindergarten is only playing and kindergarten is not a formal education. From the two respondents' answers, it was clear that the respondents' understanding related to knowledge and learning materials in kindergarten was not complete so that the respondents' understanding was absolutely wrong. The method and approach to learning by playing in kindergarten is a way to deliver material that is in accordance with the psychological development of students [7] [1] [8] [9].

The second answer classification with a percentage of $8 \%$ is based on respondent who state that "regulations do not require children who will go to primary school must go to kindergarten first". Another respondent also stated "our school does not require children who will study here to go to kindergarten first. Because not all children attend kindergarten. So, if the newest students cannot do read write and arithmetic, of course we will guide and teach them". This is a similar understanding with another respondent who states "in this school does not require students to enter kindergarten first or require them to be able to read write and do arithmetic. We know so well that the task of teaching reading, writing and arithmetic is the task of elementary school teachers. So, we will accept students who do not attend kindergarten without asking any condition". From the three respondents' answers it can be interpreted that entering and following an early age education is not a regulation that is required or not required by the government [10] [11].

The third classification with a percentage of $10 \%$, respondents stated that the location of the primary school is in the remote village and the absence of kindergarten education in the neighborhood around the child. This was identified from the respondent who state that "It does not necessary to go to kindergarten, because the primary school where I teach is far from urban areas and kindergartens do not exist there. So, most of the primary school students are not from kindergarten". This is in line with another respondent who states "At school where I teach, a lot of students come from rural area so it does not need to require the student to enter kindergarten first and this school is also a school located in a remote village where kindergarten is rare to find. So, most of the students didn't have experience studying at kindergarten. While one other respondent stated "actually, just if the regulation push us to have kindergarten education before the children go to primary school, as high school students who must graduate from primary school first, of course we will do it. However, there are parents of students who are able to send to kindergarten and some are not able to send their children to kindergarten just because of the distance matter. From those four respondents it can be identified that the location and existence of kindergarten influences the desire to enter primary school [8] [12].

The fourth classification with a percentage of $10 \%$ of respondents stated that the economic condition of the family can influence parents whether to send their children to attend kindergarten or not. A respondent stated "not all families are able to send their children to kindergarten". While another respondent stated that "from an economic point of view not all parents are able to send their children to kindergarten. Besides, there is a culturally habit in the family for not sending their children to kindergarten". This is in line with other respondent who states "the schools do not require the new students to enter kindergarten first because the location of schools in rural areas and the economic condition of the community is mediocre. So that, there is only few parentswho send their children to kindergarten". This is a similar statement of other respondent who states "the students in elementary school are, on average, come from a low-income family. This makes the new elementary school students didnot ask requirement whether they have been studied at kindergarten or not, as long as they want to learn". From the answers of the respondents it can be concluded that one reason for children who entering the early childhood education is influenced by the economic situation of the family [9] [13].

The fifth classification with a percentage of $12 \%$ of respondents stated that children who entered kindergarten and did not enter kindergarten perform no different abilities. A respondent stated "there are some kindergartens graduated who are not fluent in reading writing and arithmetic competency. In other hand, there are students who did not go to kindergarten but they are fluent in reading, counting and have neat writing". This is in line with other respondent who states "children who have finished kindergarten first may not necessarily be able to participate in learning activities properly. Although sometimes there are differencies regarding kindergarten graduated children and the children who are not graduated from kindergarten". This is different from one respondent who states "although underage children cannot read and write yet, if they already have the desire to go to school then the teacher must guide the children" While another respondent states "The important thing is the child already knows numbers and letters and can write even slightly". This is in accordance with the opinion of other respondent which states "to study at elementary school, children do not have to graduate from kindergartenbut firstly, they 
must be able to read". Based on those five respondents' statements, we can conclude that to enter elementary school, children did not require to go to kindergarten first, but they need to have any interest and basic ability to read, write and count[14] [11] [9].

The sixth classification with a percentage of $40 \%$, the respondents stated that the most important thing when children is going to study at elementary schoolis the age of the childrenmust fit completely at 6-7 years old [9] [14] [15]. This is in accordance with respondent statement who said that "children does not require to enter kindergarten first, because the important thing is the age of students must old enough and more over, kindergarten does not include in the level of compulsory school education". In line with that statement, two other respondents stated that "what is being important thing is to be fitted with the criteria for admission of new students, namely age of 6-7 years old" also said that "the main benchmark is that the child has sufficient age to enter primary school, namely the age of 6 or 7 years old, which means that the child is eligible enough to enter elementary school". Meanwhile, a respondent who is a New Student Admission Officer, stated "in the regulations, there has no requirement that children who are going to study in this school must be a kindergarten graduated. It is only stated that they must be in 6 years of age. When there is anew student who is kindergarten graduated but not 6 years old yet, then the student cannot enroll the elementary school". This is consistent with the answers of two others respondents, "the main consideration for children who will study at elementary school is the age. The ability to read, write and count are additional consideration. If the age of children is fitted to the qualification, 6 yearsold, then the children will be allowed to study at primary school". Another similar respondent's statement said that "all primary school-age children must be accepted, no matter they are from kindergarten or not. The other respondent's statement "the main consideration factor in acceptance of primary school student is age. The age of the child is at least at 6 years old. It is in line with two otherrespondents who said "if the age of the child is sufficient to enter elementary school yes no problem". This is slightly different from the response of respondent who states "children can enter primary school at the minimum age of 6 yearsold, even though they cannot read, write and count yet". Another respondent's statement "one of the requirements for new primary school students is that they have sufficient age for schools. Children are not required to be able to read, write and count'. While three other response of the respondent stated the same thing, "the important thing is that the student has already at 6 years old, where that age of the child is the age of compulsory education even though he cannot read, write and count yet".

The seventh classification with a percentage of $15 \%$ of respondents' states that entering kindergarten is a must. This was identified from one respondent's response who stated "Even though in kindergarten is not too serious in lessons, at least the child already knows his position in school, what is the teacher's duty, and he becomes more understand and able to appreciation to the teacher because in kindergarten there is also a teacher who teaches him. Although there is play more than studying, at least students already know the teacher and can appreciate the teacher and have a sense of respect towards the teacher. Children who have been sitting on kindergarten benches tend to be easier to get along with and make friends at new schools because in kindergartens they have been taught by their teachers how to make friends". This is in line with the opinion expressed by a respondent who stated "it is required to enter kindergarten first. Because although in kindergarten is not too serious in lessons at least the child already knows his position in school, and usually children who have occupied the kindergarten are easier to socialize, because even though in kindergarten play more but a little more has taught by his teacher how to make friends, manners, norms and he came to understand the basic things of school. In essence, children who have stepped on kindergarten will get more experience" While another respondent states that "children must enter kindergarten first because if children are more often stay at home with parents or caregivers, then if they do not enter kindergarten they will cry easily, are less adaptable to the environment, and their problem solving abilities are less". In addition to problem solving skills, there is a respondent statement "in kindergarten children can have new friends and train children in social interaction, reading, writing". The respondent also stated "It should have been in kindergarten first so that the mentality of the children could be better prepared". This was reinforced by respondent's answer who states "students who enroll in primary schools are required to pass kindergarten first, because the schools do not start learning from scratch and all must pass kindergarten so that there is no difference in age and ability". From this opinion of respondents, we can conclude that entering preschool education is an important matter [16] [17] [18] [19] [14] [1] [20].

From all of all answers of respondents can be classified into three types of answers, namely $45 \%$ of respondents said for various reasons do not have to enter early childhood education, $40 \%$ of respondents said they had to consider age and $15 \%$ of respondents said they had to enter early childhood education first. Generalization of those answers which conclude that there is no need to enter kindergarten before entering primary school is motivated by a variety of reasons including because of lack of accessibility to early childhood education and disparity in access education between regions, especially for those who live atremote area. The information is not yet available about the growth and development achievements of children when they will enter primary school and information is not yet available on the quality and methods of learning in early childhood education widely.

\section{CONCLUSION}

The ability of children can be identified by age, but age itself is greatly influenced by experience. Ideally, age is directly proportional to children experience, so that it can contribute to the maturity and readiness of children to 
attend further education levels. Readiness and maturity appear in the ability to integrate the experience that has been with the experience to be learned.

\section{REFERENCES}

[1] G Lansdown2011Every Child's Right to be Heard,Save Child no. $12, \quad$ p. $180, \quad$ [Online]. Available: http://www.unicef.org/files/Every_Childs_Right_to_be_Heard.p df

[2] M. Ali2017Curriculum Development for Sustainability Education(Bandung: UPI Press)

[3] D. Hendriawan, M. Ali, and Rusman2019 High School History Education and Education for Sustainable Development. An Integrated Curriculum Approach, in J. Phys.: Conf. Ser1179 012048doi: 10.1088/1742-6596/1179/1/012048

[4] M. Ali2020Pendidikan Antisipatif.pdf Pikiran Rakyat. Bandung May

[5] D. Hendriawan and Usmaedi2019Penerapan Pembelajaran Higher Order Thinking Skills (HOTS) di Sekolah Dasar $J$. Pendidikan Dasar Setiabudhi, vol. 2, no. 2, pp. 72-86

[6] M. Ali2019Research Methods In Sustainbility Education (Bandung: UPI Press)

[7] W. Damon and N. Eisenberg1998Handbook of child psychology, 5th ed.: Vol 3. Social, emotional, and personality development

[8] J. Halocha, J. Johnston2010Early childhood and primary education Readings and reflections (New York: McGraw-Hill Open University Press)

[9] E. B Hurlock1972 Child Development (McGraw-Hill series in psychology)

[10] Law The Republic Indonesia 2003National Education SystemsNumber 20

[11] Minister of Education and Culture2014Regulation The Minister of Education and Culture Republic Indonesia Number 146

[12] L. W. Nganga, 2009 Early childhood education programs in Kenya: Challenges and solutions, Early Years doi: $10.1080 / 09575140902984400$

[13] G. J. Duncan, K. M. Ziol-Guest, and A. Kalil, 2010 Earlychildhood poverty and adult attainment, behavior, and health,Child Dev. doi: 10.1111/j.1467-8624.2009.01396.x

[14] Departement of Education2004 Review of Pre-School Education in Northern Ireland

[15] J. Charema 2014 Early childhood education in Educating Zimbabwe for the 21st Century: What Every Educator Should Know

[16] M. M Clark andTim Waller2007Early Childhood Education \& Care. Sage Publication

[17] V. Derr, L. Chawla, and I. Pevec2017 Early childhood in Urban Environmental Education Review

[18] M.MClark and P. Munn 1997Education in Scotland(London: Routledge)

[19] S. Kathyet al. 2010Early Childhood Matters(London: Routledge)

[20] M. M. Black et al.2017 Early childhood development coming of age: science through the life course The Lancet, vol. 389, no. 10064, pp. 77-90, doi: 10.1016/S0140-6736(16)31389-7

[21] D. Hendriawan and L N Asriah Maulia 2020Integrated Teaching Material with Education for Sustainable Development on History Subject for High Schools Curriculum Development, in J. Phys.: Conf. Ser. 1477 042030doi:10.1088/1742$6596 / 1477 / 4 / 042030$ 